\title{
Bazı Küflerin Toprak Bazlı Mikrobiyal Yakıt Hücresindeki Potansiyellerinin İncelenmesi
}

\author{
Gamze Karanfil ${ }^{1 *}$ \\ ${ }^{1}$ Karamanoğlu Mehmetbey Üniversitesi, Mühendislik Fakültesi, Enerji Sistemleri Mühendisliği Bölümü, Karaman, Türkiye (ORCID: 0000-0002-7941-9853)
} (Illk Geliş Tarihi 2 Ocak 2020 ve Kabul Tarihi 19 Mart 2020)

(DOI: $10.31590 /$ ejosat.669422)

\begin{abstract}
ATIF/REFERENCE: Karanfil, G. (2020). Bazı Küflerin Toprak Bazlı Mikrobiyal Yakıt Hücresindeki Potansiyellerinin İncelenmesi. Avrupa Bilim ve Teknoloji Dergisi, (18), 707-710.

$\ddot{\text { Ozz}}$

Fosil yakıt tüketimi, artan enerji talepleri ve sera gazı emisyonlarına ilişkin endişeler sürdürülebilir ve yeşil enerji alternatifleri arayışını büyük ölçüde arttırmıştır. Organik atıkların geri dönüşümü en az enerji kadar önemli bir konudur. Herhangi bir işlem görmeyen organik atıklar su kirliliği veya koku problemleri gibi ciddi çevresel problemlere neden olmaktadırlar. Organik atıkların geri dönüşümü hem çevrenin korunması hem de enerji geri kazanımı konusunda önem taşımaktadırlar. Organik atıkların atık olarak değerlendirilmesi yerine, kaynak geri kazanımı için değerli biyokütle olarak düşünülmesi gerekmektedir. Mikrobiyal yakıt hücreleri özellikle son yıllarda organik maddeleri elektriğe dönüştürme sistemleri olarak büyük ilgi görmektedirler. Mikrobiyal yakıt hücreleri, organik madde gibi yenilenebilir kaynaklardan elde edilen substratları kullanarak eş zamanlı elektrik üretimi ile zararsız yan ürünlere dönüştürürler. Toprak bazlı mikrobiyal yakıt hücreleri ise toprakta doğal olarak bulunan mikroorganizmalardan ve organik maddelerden faydalı elektrik üretebilen çekici bir karbon-nötr enerji dönüşüm teknolojisidir. Yapılan çalışmada, küf içeren organik maddelerin biyodegradasyonu ile biyoeletrik üreten toprak bazlı bir mikrobiyal yakıt hücresi geliştirilmiştir. Farklı küflerin elektrik üretme potansiyellerini inceleyebilmek için ekmek küfü, peynir küfü, limon küfü ve salça küfü olacak şekilde farklı küf çeşitleri incelenmiştir. Toprak bazlı mikrobiyal yakıt hücresi sistemi aynı miktarlarda toprak+solucan gübresi + küf + su olacak şekilde kurulmuştur. Ekmek küfü $193 \mu \mathrm{W}$ ile en yüksek değeri göstermiştir. Sonuç olarak, farklı küf çeşitlerinin birbirinden farklı güç üretim potansiyellerinin ve profillerinin olduğu gözlemlenmiştir. Toprak bazlı mikrobiyal yakıt hücrelerinin organik atıklardaki küfleri kullanarak elektrik üretim potansiyellerinin yüksek olduğu sonucuna varılmıştır. Toprak bazlı mikrobiyal yakıt hücrelerinin yeşil elektrik üretimi için iyi bir yol olduğu ve aynı zamanda sağlıklı ve kirlilik içermeyen bir çevre sağlamak için organik atıkların geri dönüşümü için kullanılabileceği görülmüştür.
\end{abstract}

Anahtar Kelimeler: Enerji, Küf, Mikrobiyal Yakıt Hücresi.

\section{Investigation of Potential of Some Molds in Soil Based Microbial Fuel Cell}

\begin{abstract}
Concerns about fossil fuel consumption, increasing energy demands and greenhouse gas emissions have greatly increased the search for sustainable and green energy alternatives. Recycling of organic wastes is as important as energy. Untreated organic wastes cause serious environmental problems such as water pollution or odor problems. Recycling of organic wastes is important for both environmental protection and energy recovery. Organic wastes should be considered as valuable biomass for resource recovery rather than waste. In recent years, microbial fuel cells have attracted great interest as systems for converting organic matter into electricity. They convert substrates into harmless by-products using simultaneous generation of electricity using substrates from renewable sources such as organic matter. Soil-based microbial fuel cells are an attractive carbon-neutral energy conversion technology that can generate beneficial electricity from naturally occurring microorganisms and organic matter in the soil. In this study, a soil based microbial fuel cell producing bioelectricity by biodegradation of mold containing organic materials was developed. In order to examine the potential of different molds to produce electricity, different mold types such as bread mold, cheese mold, lemon mold and tomato paste mold were examined. The soil-based microbial fuel cell system has been installed with the same amounts of soil+vermicompost+mold+water. Bread mold showed the highest value with $193 \mu \mathrm{W}$. As a result, it was observed that different mold types have different power generation potentials and profiles. It was concluded that soil based microbial fuel cells have high electricity generation potential by using molds in organic wastes. It has been found that soil-based microbial fuel cells are a good way to generate green electricity and can also be used to recycle organic waste to ensure a healthy and pollution-free environment.
\end{abstract}
Keywords:
Energy,
Mold,
Microbial
Fuel

Cell.

\footnotetext{
* Sorumlu Yazar: Karamanoğlu Mehmetbey Üniversitesi, Mühendislik Fakültesi, Enerji Sistemleri Mühendisliği Bölümü, Karaman, Türkiye (ORCID: 0000-0002-7941-9853), gamzekaranfil@kmu.edu.tr, gamzekaranfil86@gmail.com
} 


\section{Giriş}

Sera gazı emisyonları ve fosil yakıtların tükenmesi ile ilgili endişelerin yanı sıra artan enerji talepleri, dünya çapında sıkı bir şekilde yenilenebilir enerji politikası hedeflerinin geliştirilmesine yol açmıştır. Örneğin Avrupa'da, 2020 yılına kadar yenilenebilir kaynaklarından \% 20 enerji üretimi hedefi belirlenmiştir. Bu hedefler, yenilikçi enerji teknolojilerinin geliştirilmesine olan ilgiyi arttırmaktadır (Castresana vd., 2019).

Enerji kadar önemli olan başka bir konu organik atıkların geri dönüşümüdür. Katı fazdaki organik atıklar çevrede büyük bir endişe kaynağıdır. Organik atıkların yaratmış olduğu kirlilik, büyük miktarlarda tarımsal atık birikimi, hayvan dışkısı, şehir çöpü vb. yüzleşilmesi gereken ve çözülmesi zor olan çevresel konuların başında gelmektedir (Wang vd., 2013). Gelişmekte olan birçok ülkenin katı atıklarının karakteristik analizleri, toplam katı atığın büyük bir kısmının (\% 80'den fazla), genellikle geri dönüşüm veya kaynak geri kazanımı için çok fazla dikkat çekmeyen organik atıklardan oluştuğu belirlenmiştir (Moqsud vd., 2013). Küresel bir bakış açısına göre, organik atıklar karlı olabilecek ve atıktan enerji konseptine uyan değerli bir kaynak olarak görülmelidir (Khudzari vd., 2016).

Mikrobiyal yakıt hücreleri (MYH); katalizör olarak mikroorganizma kullanan umut verici bir anaerobik atık arıtma cihazı olarak, çeşitli organik atıklardan elektrik üreten biyo-elektrokimyasal dönüştürücülerdir (Jia vd., 2013; Moqsud vd., 2015). Bakteriler tarafından üretilen elektrik akımı, 1911'de Potter tarafindan gözlenmiş olmasına rağmen, bu alanda sonraki 50 yıl boyunca sınırlı uygulanabilir sonuçlar elde edilmiştir. Bununla birlikte 1990'ların başlarında, yakıt hücrelerinin üzerindeki ilginin artmasıyla birlikte, MYH de gelecek vaat eden teknolojiler arasında kabul edilmiştir. Geleneksel bir MYH, bir proton değişim membranı (PEM) ile fiziksel olarak ayrılmış anot ve katot bölmelerinden oluşur. Anottaki aktif biyokatalizör organik substratları okside eder ve elektronlar ve protonlar üretir. Protonlar, katot bölmesine PEM yoluyla iletilir ve elektronlar dış devre boyunca taşınır. Protonlar ve elektronlar, katot bölmesinde, oksijenin suya paralel olarak indirgenmesiyle reaksiyona girer (Rahimnejad vd., 2015).

Toprak bazlı mikrobiyal yakıt hücreleri (bitki mikrobiyal yakıt hücreleri olarak da adlandırılmaktadır), toprakta doğal olarak bulunan organik maddede depolanan kimyasal enerjiyi, elektrokimyasal olarak aktif mikroorganizmaların etkisi ile doğrudan elektrik enerjisine dönüştüren sistemlerdir. Özellikle anottaki mikroorganizmalar, toprak içinde bulunan organik maddeyi okside eder, böylece elektron alışverişi yapar ve protonları aktarır. Elektronlar, harici bir devre boyunca katoda ilerler, elektrik üretir, protonlar ise katoda toprak yoluyla iletilir. Katotta oksijen, $\mathrm{H}_{2} \mathrm{O}$ üretmek için elektron ve protonlarla reaksiyona girer (Castresana vd., 2019). Toprak bazlı MYH'nin şematik gösterimi Şekil 1'de verilmiştir.

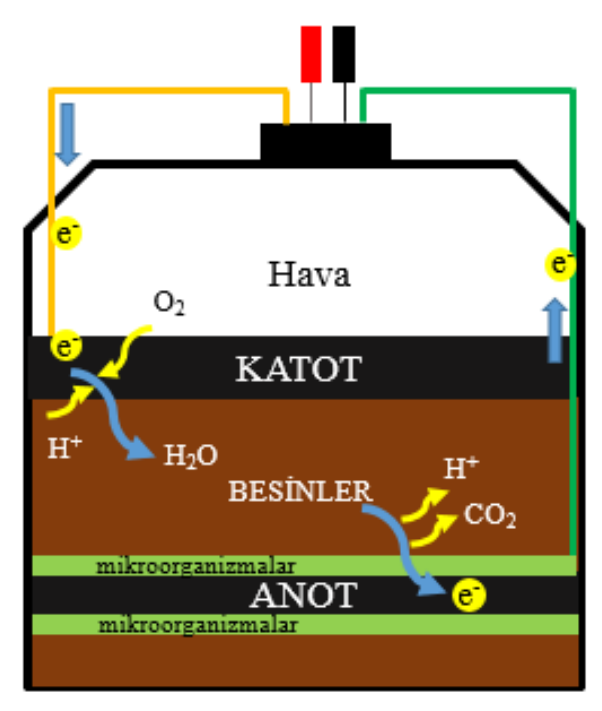

Şekil 1. Toprak bazlı mikrobiyal yakıt hücresinin şematik gösterimi

Tüm mantarlar gibi küfler de yaşadıkları organik maddeden heterotrofi kullanarak fotosentez yoluyla olmadan enerji üretirler. Tipik olarak küfler, esasen hiphal uçlarından hidrolitik enzimler salgılarlar (Karanfil, 2019).

Yapılan çalışmada organik atığa neden olan küf çeşitlerinden bazılarının toprak bazlı mikrobiyal yakıt hücresinde kullanımının potansiyeli incelenmiştir. Küf çeşitleri seçilirken evsel atıklara en çok neden olan ekmek küfü, peynir küfü, limon küfü ve salça küfü belirlenmiş ve bu küflerin toprak bazlı mikrobiyal yakıt hücresinde elektrik üretim potansiyelleri izlenmiş̧ir. 


\section{Materyal ve Metot}

Seçilen küflerin toprak bazlı MYH'inde elektrik üretim potansiyelinin belirlenmesi için FuelCell Store'dan satın alınan MudWatt Microbial Fuel Cell kiti kullanılmıştır. Aynı miktarlarda toprak, solucan gübresi, küf ve su ile bir karışım hazırlanarak kitin içerisine 1 $\mathrm{cm}$ yüksekliğinde eklenmiştir. Anot ve katot elektrotları aralarında $2.5 \mathrm{~cm}$ toprak karışımından olacak şekilde yerleştirilmiştir. Toprağa daldırılmış anot ve havaya maruz kalan katot titanyum tel ile bağlanmıştır. Anot (Yeşil, $8 \mathrm{~cm}$ çap ve $0,5 \mathrm{~cm}$ kalınlıkta) ve katot (Turuncu, $8.5 \mathrm{~cm}$ çap ve $1 \mathrm{~cm}$ kalınlıkta) grafit elyaf keçeden yapılmıştır. Kapasitörlü ve LED'li küçük bir devre kartı, elektriğin üretildiğinin görünür göstergeleridir. Ayrıca, MudWatt Explorer App uygulaması yanıp sönme sayısını LED 1şığından üretilen (mikroWatt'ta $(\mu \mathrm{W}))$ akıma dönüştürmek için kullanılmıştır. Ölçümler 15 gün boyunca günde bir kez yapılmıştır. Toprak bazl1MYH'nin tasarımı Şekil 2'de verilmiştir.

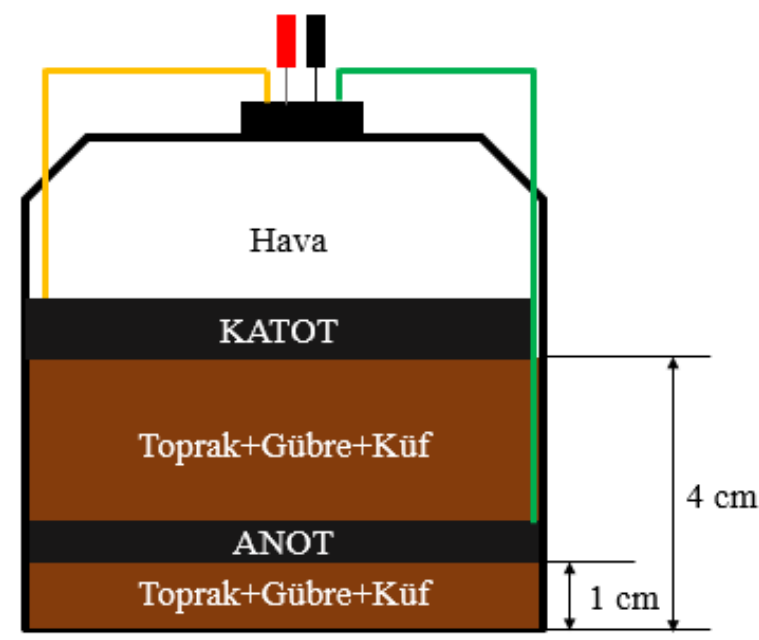

Şekil 2. Toprak bazlı mikrobiyal yakıt hücresi tasarımı

\section{Araştırma Sonuçları ve Tartışma}

Seçilen küf çeşitlerinin toprak bazlı MYH'inde gücündeki değişikliklerin 15 günlük izlenen sonuçları Şekil 3 'te verilmiştir. Ölçülen sonuçlarda ani güç değişiklikleri gözlenmiştir. Güç düşüşü olgusu, karbon kaynağının toprak bazlı MYH'nin anaerobik bölgesi içindeki bakterilerin metabolizmasını sınırladığı için gerçekleştiği düşünülmektedir. Başka bir deyişle, organik maddeler her tükenmeye başladığında, toprak bazlı MYH'inde düşük mikrobiyal metabolizma nedeniyle elektrik üretimi azalacaktır (Barua ve Deka, 2010). Mevcut çalışmada bulunan güç değişimleri profili farklı MHY sistemleri için literatür ile benzerlik göstermektedir (Jia ve ark., 2013; Moqsud ve ark., 2015; Khudzari ve ark., 2016; Yu ve ark., 2019). Ekmek ekmek küfü, peynir küfü, limon küfü ve salça küfü elektrik üretim potansiyelini belirlemek için, toprak bazlı MYH sistemi toprak+solucan gübresi+küf olarak kurulmuştur. Şekil 3 ’ten de görüleceği üzere ekmek küfü ile kurulan sistemde 3. gün sonunda güç elde edilmiş ve 15 günlük ölçüm süresinde maksimum $193 \mu \mathrm{W}$ güç üretimi gözlenmiştir (Karanfil, 2019). Peynir küfü ile kurulan toprak bazlı MHY sisteminde ilk günden itibaren güç üretimi gözlenmiştir ve 14. güne kadar lineer bir artı̧̧ mevcuttur. 14. günde en yüksek güç değeri $(181 \mu \mathrm{W})$ elde edildikten sonra ani bir düşüş görülmüştür. Limon küfü ile kurulan toprak bazlı MHY sisteminde sadece 5 gün ve çok küçük değerlerde güç üretimi gözlenmiştir. Son olarak salça küfü ile kurulan toprak bazlı MYH sisteminden elektrik üretimi gözlenmemiştir. 


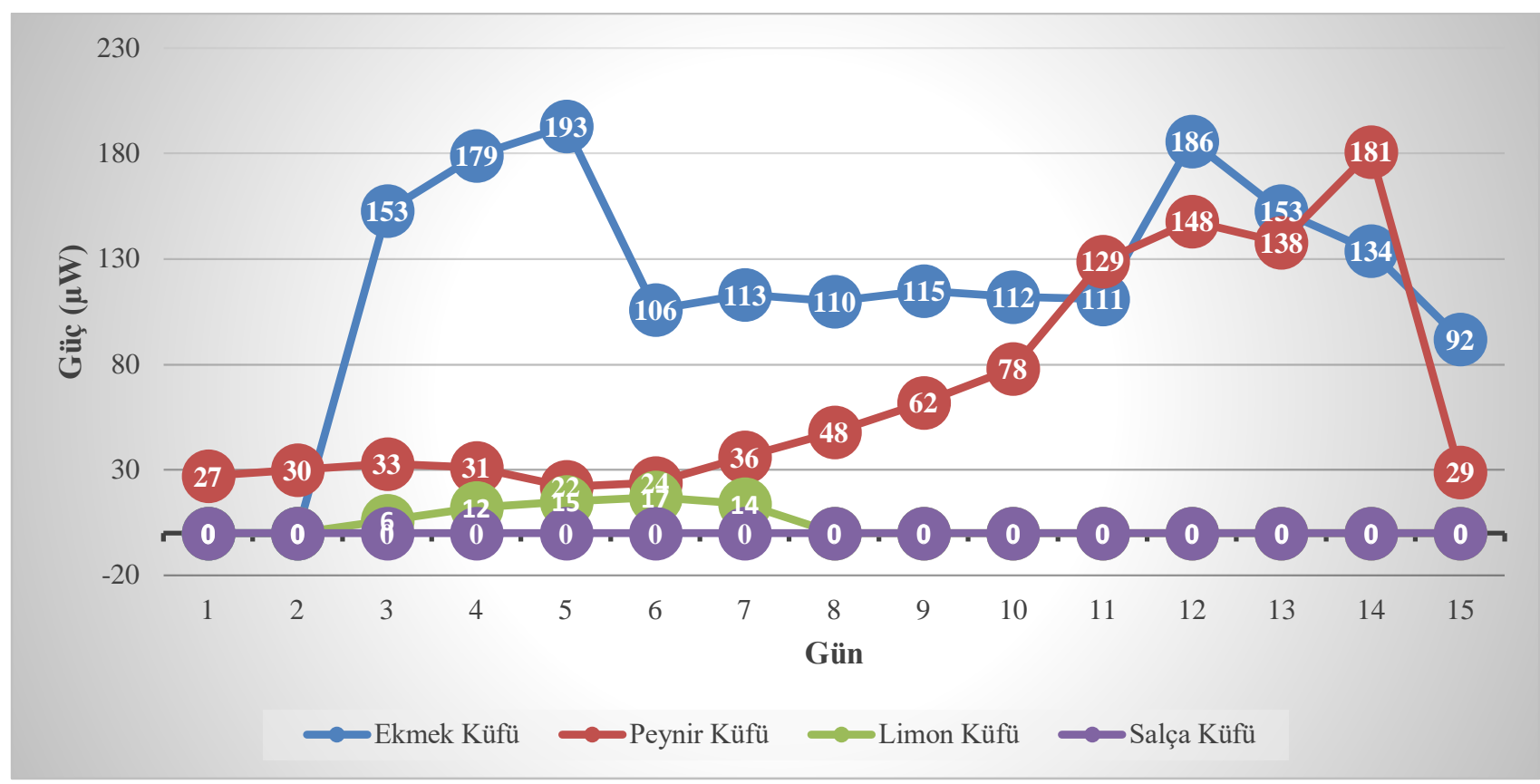

Şekil 3. Seçili küflerin toprak bazlı MYH performansları

\section{Sonuç}

Mevcut çalışmada evsel atıklarıda en çok organik atığa neden olan küflerin toprak bazlı MYH elektrik üretme potansiyelleri belirlenmiştir. Farklı küf çeşitlerinin birbirinden farklı güç üretim potansiyellerinin ve profillerinin olduğu sonuçlardan açıkça görülmektedir. Sonraki çalışmalarda farklı küf çeşitleri ile bu küflerin birlikte kullanımı incelenecektir. Ayrıca ölçümlerin hassaslığını arttırmak için çeşitli sensörler eklenerek sürekli izleme sistemi oluşturulacaktır. Ayrıca küf kullanılan toprak bazlı MHY sisteminin seralardaki kullanımına ilişkin çalışmalara öncülük etmesi adına bitki yetiştirilmesindeki etkisi de incelenecektir.

\section{Teșekkür}

Ekmek küfüyle ilgili öncü çalışmaları yaparak küf potansiyellerini araştırma alanı olarak belirlememizi sağlayan bitirme tezi öğrencim Hakan Benlioğlu'na teşekkür ederim.

\section{Kaynakça}

Barua, P.K. ve Deka, D., 2010. "Electricity generation from biowaste based microbialfuel cells", International Journal of Energy, Information and Communications 1 (1), 77.

Castresana, P.A., Martinez, S.M., Freeman, E., Eslava, S., Lorenzo, M.D. 2019. "Electricity generation from moss with light-driven microbial fuel cells", Electrochimica Acta, 298, 934-942.

Jia, J., Tang, Y., Liu, B., Wu, D., Ren, N., Xing, D. 2013. "Electricity generation from food wastes and microbial community structure in microbial fuel cells", Bioresource Technology, 144, 94-99.

Karanfil, G. 2019. "Investigation Of The Effect Of Bread Mold On Soll Based Microbial Fuel Cell”, 4th International Energy \&Engineering Congress, Gaziantep Üniversitesi, Gaziantep, 775-778.

Khudzari, J. Md., Tartakovsky, B., Raghavan, G.S.V. 2016. "Effect of $\mathrm{C} / \mathrm{N}$ ratio and salinity on power generation in compost microbial fuel cells", Waste Managment, 48, 135-142.

Moqsud, M.A., Omine, K., Yasufuku, N., Hyodo, M., Nakata, Y. 2013. "Microbial fuel cell (MFC) for bioelectricity generation from organic wastes", Waste Managment, 33, 2465-2469.

Moqsud, M.A., Yoshitake, J., Bushra, Q.S., Hyodo, M., Omine, K., Strick, D. 2015. "Compost in plant microbial fuel cell for bioelectricity generation", Waste Managment, 36, 63-69.

Rahimnejad, M., Adhami, A., Darvari, S., Zirepour, A., Oh, S.-E. 2015. "Microbial fuel cell as new technology for bioelectricity generation: A review", Alexandria Engineering Journal, 54, 745-756.

Wang, C.-T., Liao, F.-Y., Liu, K.-S. 2013. "Electrical analysis of compost solid phase microbial fuel cell", International Journal of Hydrogen Energy, 38, 11124-11130.

Yu, B., Li, Y., Feng, L. 2019. "Enhancing the performance of soil microbial fuel cells by using a bentonite-Fe and $\mathrm{Fe}_{3} \mathrm{O}_{4} \mathrm{modified}$ anode", Journal of Hazardous Materials 377, 70-77. 